Silent heat occurred with different frequencies in the breed groups, with a range of $0 \cdot 25-1 \cdot 40$ silent heats per adult ewe per breeding season. The average of silent heats expressed as a percentage of total cycles detected was 7 (62 per cent of those occurring after the shortest day).

Post-partum heat was experienced in 56 per cent of lactating Suffolk ewes, when the length of daylight (January-March) was 10-12 hr., and the length of the lactation ancstrus ranged from 1 to 9 weeks. The post-partum conception-rate was 50 per cent, and it depended on suckling conditions.

This work is being carried out in the Animal Research Station, Cambridge, while on study leave from the Fouad I University of Egypt. It is still in progress, and detailed results will be published else. where. I am indebted to Dr. John Hammond for his continuous advice and encouragement.

School of Agriculture,

E. S. E. HAFEZ

Cambridge. July 10.

"Johansson, I., and Hansson, A., Ann. Agric. Coll. Sweden, 11, 145 (1943). Whithurst, v. E., Grown, R. M., Phillips, R. W., and Spencer, P. A.'
Bull. Flor. Agric. Exp. Sta., No. 429, 34 (1947).

* Hammond, jun., J., J. Agric. Sci., 34, 97 (1944).

Hammond, sen., J., U.N. Sci. Conf. on Conser. and Utiliz. of Resources, 11, (b), 22 (1949).

- Yeates, N. T. M., J. Agric. Sci., 39, 1 (1949).

\section{Experimental Rearing of the British Harvest Mite to the Adult Stage}

THE periodical revivals of attempts at rearing harvest mites during the past half-century have led to few successes, and $I$ rombicula autumnalis, the British harvest mite, has evaded the efforts of Hirst ${ }^{1}$, André2, $\mathrm{Keay}^{3}$, and others to rear it further than the nymphal stage. In view of the permanent hypogean existence of the nymphs and adults at some considerable depth below the surface of the soil (Cockings) ${ }^{4}$, it is not surprising that difficulties have been encountered in trying to discover the food and environmental requirements of the post-larval stages.

Miyajims and Okumura first gained success in rearing $T$. akamushi from the larva to the adult, but their account omitted much needful detail. The American workers Melvin ${ }^{6}$, Michener ${ }^{7}$ and Jenkins ${ }^{8}$ successfully maintained colonies of Eutrombicula batatas in 1946, mainly for the purpose of testing acaricides on the mites. The rearing methods adopted, whether successful or otherwise, depended primarily on culturing the mites either in a layer of some suitable medium, like moist sterile soil, or in moist cotton wool, and mosquito eggs were recommended as the best food for rearing the nymphs and adults. The methods employed by previous workers were unsuitable for following closely the progressive change of form of individual mites through the phases of their peculiar and complex post-embryonic growth-cycle. Since my aim in rearing this mite was primarily to include its peculiar type of development in a study on growth in the Acarina, a convenient method had to be devised. In 1949, after many attempts during previous years, the following method turned out to be successful.

The larvæ, collected from the field, were nourished on young mice. These were kept individually inside inverted glass funnels resting upon a wire gauze over Petri dishes, so that the engorged larvæ were trapped as they fell off the host. The engorged larvæ

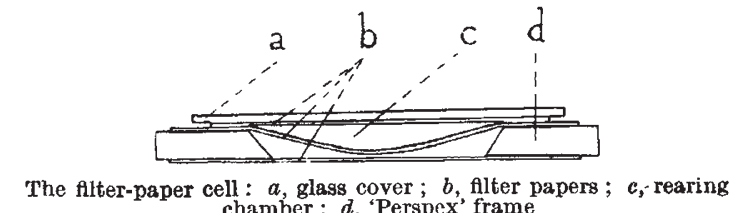

chamber ; $d$, 'Perspex' frame

were transferred to special filter-paper cells: each cell consisted of a 'Perspex' framework (with 4-cm. sides, $0.3 \mathrm{~cm}$. thick, and with a central aperture) which supported two squares of filter paper of appropriate size, one of which was depressed into the aperture so that the space between the two filter papers formed the chamber for housing the engorged larvæ and later stages (see diagram). The nymphs fed best on a mixture of moist chicken fæces, agar, yeast and molasses, the three last being constituents of a food used for culturing Drosophila. The nymphs showed no desire to feed on the eggs of Aedes cegypti, and both young and old nymphs seemed incapable of piercing the outer membranes even after the eggs were moistened. The fully engorged nymphs imbibe water and increase in bulk considerably before elongating and exhibiting the pupa-like features of the pre-adult transition stage, which closely resembles that preceding the emergence of the active nymph. The mortality-rate of fed nymphs was very high, but six adults of various sizes were obtained; the pre-adult developmental phase lasted about thirtysix days at room temperature, 100 per cent relative humidity and about twenty-eight days at $25^{\circ} \mathrm{C}$., 100 per cent relative humidity. Attempts to force egg-laying at high temperatures failed.

So far as I am aware, this is the first time that $T$. autumnalis has been reared experimentally from the larva to the adult stage. Details of the method are included in a completed paper on the growth and development of this mite, which I hope to publish elsewhere.

Department of Zoology,

University of Edinburgh. July 4.

${ }^{1}$ Hirst, S., J. Econ. Biol., 10, 73 (1915).

2 André, M., Mem. Soc. Zool., Fr., 29, 39 (1920).

' Keay, G., J. Anim. Ecol., 6, 23 (1937).

- Cockings, K. L., Bull. Ent. Res., 39, 281 (1948).

s Miyajima, M., and Okumura, T., Kitisato Arch. Exp. Med., 1, 1 (1917).

${ }^{-}$Melvin, R., Ann. Ent. Soc. Amer., 39, 143 (1946).

7 Michener, C, D., Ann. Ent. Soc. Amer., 39, 101 (1946).

s Jenkins, D. W., Ann. Ent. Soc. Amer., 40, 56 (1947).

\section{An Inhibitor of Salt Absorption in Root Tissue of Red Beet}

De Kock and Hunter reported in Nature of Septem. ber 9, p. 440, the extraction from, the seeds of sugar beet of a water-soluble oil which inhibited the respiration of root tissues and the germination of seeds.

Recent experiments in this Department have indicated the presence in red beetroot during winter storage of a water-soluble substance which inhibits the ability of beetroot cells to absorb inorganic salts from solutions. This was shown by the temporary cessation of salt absorption when a concentrated waterextract of beetroot was added to a solution from which disks of tissue were absorbing manganese chloride. The addition to such solutions of the residues from chloroform extractions of ground-up 